\title{
The Journey Home: Violence, Anchoring, and Refugee Decisions to Return
}

FATEN GHOSN University of Arizona

TIFFANY S. CHU Tucson Police Department

MIRANDA SIMON University of Essex

ALEX BRAITHWAITE University of Arizona

MICHAEL FRITH University College London

JOANNA JANDALI Arizona State University

$W$

hile the UNHCR promotes voluntary repatriation as the preferred solution to refugee situations, there is little understanding of variation in refugees' preferences regarding return. We develop a theoretical framework suggesting two mechanisms influencing refugees' preferences. First, refugees' lived experiences in their country of origin prior to displacement and in their new host country create a trade-off in feelings of being anchored to their origin or host country. Second, firsthand exposure to traumas of war provides some refugees with a sense of competency and self-efficacy, leading them to prefer to return home. We test these relationships with data from a survey among Syrian refugees hosted in Lebanon. We find refugees exposed to violence during the war have a sense of attachment to Syria and are most likely to prefer return. Refugees who have developed a detachment from Syria or an attachment to Lebanon are less likely to prefer return.

\section{INTRODUCTION}

$\mathbf{T}$ he international community promotes three durable solutions to refugee situations: integration of refugees into host countries, resettlement to third countries, and voluntary repatriation to countries of origin. While all three may be viable under certain circumstances, voluntary repatriation has long been promoted by the office of the High Commissioner for Refugees (UNHCR) as the preferred solution (Barnett and Finnemore 2004; Hammerstad 2000). Accordingly, voluntary repatriation programs have been attempted in the wake of post-Cold War conflicts in Rwanda, Bosnia, Croatia, and Sudan. However, there are negative consequences to promoting repatriation including increasing levels of violations of non-refoulement $t^{1}$ and growing

Faten Ghosn (D), Full Professor, School of Government and Public Policy, University of Arizona, fghosn@arizona.edu.

Tiffany S. Chu, Analysis Division Lead Analyst, Tucson Police Department, tiffanyschu26@gmail.com.

Miranda Simon (D), Assistant Professor, Department of Government, University of Essex, miranda.simon@essex.ac.uk.

Alex Braithwaite (D), Professor, School of Government and Public Policy, University of Arizona, abraith@arizona.edu.

Michael Frith (D), Post-doctoral Research Associate, Department of Security and Crime Science, University College London, michael. frith@ucl.ac.uk.

Joanna Jandali, JD Candidate, Sandra Day O'Connor College of Law, Arizona State University, joanna.jandali@gmail.com.

Received: July 16, 2020; revised: March 16, 2021; accepted: April 13, 2021. First published online: May 17, 2021.

\footnotetext{
${ }^{1}$ For example, several developed states, including Australia, Italy, and the US, have been criticized for refusing to rescue forced
}

numbers of refugees returning home before conditions are safe for them to do so (McKernan 2019; Schwartz 2019).

Those debating repatriation focus on the obligations and actions of host states and seemingly assume refugees hold uniform or unimportant opinions regarding if, and when, to return to their countries of origin. We contend the preferences and abilities of refugees should not be overlooked. We focus attention on understanding conditions under which refugees would prefer to return to their countries of origin. In comparison to the voluminous literature on the causes of forced displacement, little research explores the conditions under which refugees repatriate. To contribute evidence on refugee preferences for return, we develop a theoretical framework, adapting literature from psychology, in which we argue refugees vary in terms of how anchored they feel to either their country of origin or their current host country. We claim this variation depends, in part, upon the nature of their lived experiences, both in their country of origin prior to displacement and subsequently in the host country.

We begin by exploring two features of refugees' predisplacement exposure to violence. First, we note that individuals more deeply anchored to their origin locations were more likely to stay at those locations for a longer duration before being displaced and, thus, were more likely to be exposed to violence. Second, their exposure to violence imbued them with an appreciation of their tolerance to unstable conditions.

migrants at peril at their borders and for deporting asylum seekers that had already arrived in their countries. 
Through this exposure, individuals develop "expertise" in assessing risks associated with violence. That is, they develop efficacy in surviving insecurity. By contrast, refugees not directly exposed to violence before fleeing are unsure of the level of threat associated with returning and unwilling to accept the risk of doing so. Both the underlying anchoring and the newly developed understanding of risk make refugees who stayed at home longer and were exposed to violence more likely to desire a return to their countries of origin.

What anchors refugees to locations does not end when they flee their homes. We contend an individual's desire as to whether or not to return home will also be affected by the extent to which they have developed ties and dependencies in their new host state. Individuals who have developed social anchors in the host state should, naturally, be less likely to desire a return to their country of origin.

We test these theoretical arguments using an original survey, carried out in Summer 2018 among nearly 2,000 Syrian refugees hosted in Lebanon. We use the survey to identify the influence of conflict exposure and anchoring (or attachment) to both Syria and Lebanon on refugees' preferences for the future. We employ both observational and experimental elements from the survey for this purpose. We find those who have been exposed to violence prior to their departure and left when most of their hometown had fled are most likely to prefer returning to Syria. Refugees who discussed the matter of fleeing as well as those who find it easy to cross the Lebanese/Syrian border are more likely to prefer remaining in Lebanon.

This paper contributes to scholarship on refugee movement in two important ways. First, most research on refugee repatriation takes the perspective of nationstates, exploring their obligations to and violations of international refugee law. We examine the agency and preferences of refugees themselves. Second, we develop a novel theory of refugee repatriation that accounts for both individuals' past exposure to violence and their sense of attachment to both their country of origin and their current host country.

\section{REPATRIATION AS THE PREFERRED SOLUTION}

As the number of refugees globally has increased, the traditional solutions promoted by the UNHCR have become collectively insufficient in alleviating refugee hardship. In 2016, "only $2.5 \%$ of refugees $(552,000)$ were able to return to their home countries ... and even fewer, $0.8 \%$ (or 189,300), were resettled through formal settlement programs. An even smaller percent age $(0.001 \%$, or 23,000$)$ were naturalized as citizens" in host countries (Ferris 2018).

While collectively insufficient, these numbers suggest repatriation - or return to the country of origin - is the most frequently observed "solution." These rates speak to a flaw in the durable solutions model: public prioritization of repatriation gives current and potential host states an excuse to discount and, thus, shirk their contributions to integration and resettlement alternatives. Since repatriation is considered the preferred solution, local integration has morphed into underresourced, temporary hosting, while resettlement quota numbers have receded dramatically (Salehyan 2018). More than eight of every ten refugees are hosted by states neighboring their countries of origin. These are typically developing countries requiring more assistance than is available to meet the demands associated with hosting refugees (Bradley 2013). There are several domestic challenges associated with refugee hosting and integration. Refugees are often challenged by inadequate language skills and culture shocks (Akar and Erdoğdu 2019). At the same time, citizen populations in host countries often struggle to accept refugee populations, especially given the large numbers in protracted scenarios (Ghosn, Braithwaite, and Chu 2019).

Given that developing host states are stretched thin and developed states lack political will to open their doors, it makes sense that repatriation is identified as the preferred solution for refugee crises (Barnett and Finnemore 2004; Hammerstad 2000). International law dictates four preconditions for the initiation of large scale repatriation programs: (1) there is a fundamental change of circumstances in the country of origin that would reduce the risk associated with return; (2) the decision to return is voluntary in nature; (3) a tripartite agreement is signed between the origin state, host country, and the UNHCR; and (4) the return process happens in safety and dignity. In practice, all conditions are rarely met, especially when host governments pressure both the UNHCR and refugees themselves to return. The lack of accountability toward upholding these conditions leads to commentary questioning whether observed returns of refugees are truly voluntary (Black and Gent 2006).

Repatriation as a solution is not without its detractors. Critics argue such a strong focus upon repatriation encourages overburdened host states to violate norms of non-refoulement (Barnett 2001). Repatriation is considered to be a way for host states to release themselves from their duty of hosting refugees, thus eroding the human right to asylum (Adelman and Barkan 2011). In response to the growing economic and social burden they face, governments often frame hosting as a temporary solution, with many of them pushing for refugees to leave as soon as possible (Orchard 2014). This trend has resulted in growing numbers of refugees returning to states lacking the capacity to absorb them. This includes hundreds of thousands of Syrians who have been encouraged to voluntarily sign repatriation paperwork and depart Turkey even while the civil war at home rages on (McKernan 2019). Similarly, more than 80,000 Somali refugees have returned home from Kenya since a repatriation program was agreed between UNHCR, Kenya, and Somalia in 2013, with almost 3,000 of these individuals having again since been displaced from Somalia (Loughran and Aden 2019).

While repatriation as a program is clearly problematic, refugees in many situations do appear to hold strong preferences to return home, even while violence 
continues in their country of origin (Chu 2019; Stein and Cuny 1994). How might we explain this incongruity between public commentary and refugee preferences? Academic scholarship often views decisions regarding return through the same "push and pull" framework used to explain their initial displacement (Davenport, Moore, and Poe 2003; Moore and Shellman 2007; Schmeidl 1997). Return is deemed most likely when circumstances at home are better than conditions in exile (Koser 1997).

Under this framework, refugees returning during conflict may at first blush appear somewhat puzzling. However, refugee return under continued duress in the country of origin may not be so surprising given the dwindling opportunities for resettlement in third countries and the worsening conditions on the ground in temporary host countries. For example, Syrian refugees who have returned while their civil war is ongoing have commonly cited limited opportunities in the host state and a shift in aid resources to areas in Syria as reasons for their return (Al-Khateeb and Toumeh 2017). In addition, evidence suggests host state restrictions on movement, economic opportunities, and access to welfare provisions such as medical care to refugees, also make it difficult to sustain livelihoods abroad, in turn increasing the likelihood of return (Parkinson and Behrouzan 2015). In some instances, ultimatums by host states may motivate return migration. For example, Sudanese refugees in Israel must choose between repatriation with a stipend or the threat of detention (Gerver 2014).

Existing scholarship on refugee return has not fully addressed several issues. Many studies homogenize refugees' experiences and the effect these have on their preferences. ${ }^{2}$ Such studies assume refugees are displaced by violence and thus deterred from returning to their home countries until the conflict has ended. However, there is variation in refugees' exposure to violence, the factors motivating their decisions to flee, and the preferences they hold regarding returning home. Accordingly, many struggle to explain why a majority of surveyed Syrian refugees want to return home (Alsharabati and Nammour 2017; Berlin Social Science Center 2015). Even these survey-based studies neglect to address questions regarding the timing of potential repatriation. Thus, as refugees are observed returning while violence continues in their country of origin, a more comprehensive understanding of why this is happening is required.

\section{UNDERSTANDING REFUGEES' MOVEMENT PREFERENCES}

Little research explores conditions under which refugees are likely to repatriate, and even less examines how refugees' preferences affect this process or how these compare with preferences to remain in the host

\footnotetext{
${ }^{2}$ Emerging literature has begun to challenge this narrative. See, e.g., Steele (2019) and Schwartz (2019).
}

state. In this section, we derive a set of testable hypotheses from a logic based upon notions of exposure to violence and attachment to place.

Adapting Kuhlman's (1990) framework of refugee integration in host countries, we suggest refugee decision making is affected by four categories of factors, as summarized in Table 1. While we acknowledge the factors across these different categories are interrelated, for the sake of simplicity we consider each category separately.

Several demographic characteristics of the refugee's preflight life likely affected their initial decision to flee and could influence whether they later wish to return home. Women and children are often early movers in displacement and, as a consequence, are a high proportion of the global refugee population $-76 \%$ of Syrian refugees are women and/or children. ${ }^{3}$ Wealthier individuals have more resources to flee early (Schon 2019) and can afford to stay longer in exile in a host country. Individuals maintaining gainful employment in their hometowns may be more reluctant to flee than unemployed individuals who might be expected to depart sooner to seek out opportunities elsewhere (Adhikari 2012). Finally, individuals with social ties to kin abroad may be more likely to travel to join them once conflict breaks out. These logics also suggest women and children, wealthy individuals, those without job prospects at home, and those with stronger ties to displaced individuals are less likely to want to return home.

Flight factors refer to changing conditions and contexts influencing an individual's decision to flee or stay in their country of origin. Such decisions are driven in the aggregate by root causes of flight. The outbreak of war destroys infrastructure and inhibits economic opportunities, making an individual feel as if they have no choice but to leave (Adhikari 2012; Moore and Shellman 2006; Steele 2009). Individual decisions are also affected by interpersonal relationships and whether or not members of their familial and social networks have chosen to flee or stay. Decisions regarding whether to return likely involve a reassessment of these flight factors and perceptions of safety or harm associated with returning to origin locations.

We also believe host-related factors or aspects of the refugee's situation in the host country influence decisions about future journeys. Such conditions likely include the availability of economic opportunities such as housing, employment, and access to social services provided by the state or nongovernmental organizations. Moreover, refugees exposed to verbal or physical assault by government agents or native populations likely feel less safe in the host country and are more likely to consider returning home.

Decisions are also affected by the portfolio of policies across multiple domains that support refugee

\footnotetext{
${ }^{3}$ data2.unhcr.org/en/news/13033. To provide context for our study, $52 \%$ of the Syrian refugees registered in Lebanon in May 2015 (when the UNHCR stopped registration) were female and 54\% were children.
} 
TABLE 1. Framework for Refugee Decision Making about Future Movements

\begin{tabular}{llll}
\hline Preflight characteristics & Flight-related factors & Host-related factors & Policies \\
\hline Demographic variables & Root causes of flight & Access to employment, housing, services & Host \\
$\begin{array}{l}\text { Socioeconomic background } \\
\text { Ethnocultural }\end{array}$ & Decision-making context & Physical/verbal assault & Home \\
& Social ties & Wage theft/forced labor & International \\
\hline
\end{tabular}

populations or define their rights. In the host country, this includes laws affecting the ability to work, freedom of movement, and any rights to pursue naturalization. In the home country, policies include rules around forced conscription and whether the incumbent government would grant minority and opposition groups amnesty upon return. Finally, international policies might influence the ability of relief organizations to provide aid, the openness of transit routes, and the availability of resettlement opportunities.

This pretheoretical framework presents factors influencing refugee decisions about the future. However, refugees may be swayed by any or all factors, making it difficult to tease out which will influence individual refugees. Therefore, we develop a theoretical argument to prioritize factors.

\section{Refugees and the Anchoring Effects of Attachment to Place}

In developing a theoretical account for variation in refugee preferences regarding returning to their countries of origin, we apply the concept of anchoring. We suggest individuals are inclined to return home if they feel attachment to their country of origin and disinclined if not or if they enjoy attachments to their new host country.

We assume individual decision making is subject to bounded rationality via limits on capacity (Simon 1972) and cognitive heuristics serve to reduce the complexity of assessments and calculations, enabling individuals to make difficult decisions more efficiently (Tversky and Kahneman 1974) but also more strategically (Johnson 2020). Refugee decision making is surely subject to these efficiencies and strategic adaptations. We suggest two ways this theoretical approach is valuable for understanding refugee decision making. First, displaced individuals are challenged by limited information, uncertain levels of risk, and constraints on their ability to act independently in the future. As such, anchoring effects are critical to refugees' decisionmaking processes, ${ }^{4}$ informing which factors have the greatest bearing upon their preferred course of action.

Second, anchor biases affect judgements of selfefficacy and predictions of future performance. Existing explanations of refugee decision making speak to the shaping role of local context, yet they often erro-

\footnotetext{
${ }^{4}$ Our logic also fills a gap in the literature on anchoring when it comes to understanding how individual differences and past experience may compound or mitigate the anchoring effect (Furnham and Boo 2011).
}

neously homogenize refugee experiences such as exposure to violence and decisions to flee. Our anchor-based logic suggests individuals are exposed to different degrees of anchoring depending upon variation in these kinds of lived experiences. This anchoring bias refers to a process in which an individual's initial decision (e.g., whether to flee) is anchored to a specific starting point. It is assumed individuals' decisions will be biased toward this starting point when making subsequent choices, especially when faced with complexity and uncertainty (Tversky and Kahneman 1974). However, as additional information becomes available, individuals will adjust their anchor and attachment to their anchor accordingly (Slovic 1972).

Broader research on decision making demonstrates individual judgements of self-efficacy have a strong bearing on adjustments to subsequent decision making and behavior. Cervone and Peake (1986) demonstrate this in a generic setting, presenting study participants with random initial values of high or low levels of performance and then asking them to judge their own capabilities for the problem-solving task before them. High-anchor participants regarded themselves with higher levels of self-efficacy than did low-anchor participants. These judgments corresponded to subsequent task performance, with participants who judged themselves at higher levels of self-efficacy demonstrating greater task persistence. Switzer and Sniezek (1991) subsequently examined the anchoring effect on predictions of future performance. While they were unable to draw any conclusive findings on the effect of the anchors on actual performance, they did find a notable relationship between anchors and individual selfjudgment on likely future effort and performance.

What does this tell us about refugee decision making specifically? We argue an important first effect of anchoring is an individual's exposure to violence. ${ }^{5}$ Individuals are forced to flee from their homes as conflict closes in upon them, when they are stripped of civil liberties and rights, and when they are targeted by repressive government actions (Davenport, Moore, and Poe 2003; Moore and Shellman 2007; Neumayer 2004; Schmeidl 1997). An individual's decision to flee is informed by their perception of risk. Individuals from areas of conflict or disaster alter their risk preferences based on prior exposure to similar events (Eckel, El-Gamal, and Wilson 2009; Voors et al. 2012). For example, victims of violence display strong preferences

\footnotetext{
$\overline{5}$ Exposure to violence encompasses direct experiences with violence, as well as witnessing violence.
} 
for high degrees of certainty regarding future decisions (Callen et al. 2014), and victims of natural disasters subsequently display higher risk aversion in anticipation of future events (Cameron and Shah 2015). Exposure to violence can also result in heightened anxiety, depression, perceived insecurity, vulnerability, and posttraumatic stress disorder (PTSD). A prominent feature of PTSD is an avoidance of stimuli associated with a traumatic event (Fleurkens, Rinck, and Van Minnen 2014).

These logics suggest refugees exposed to violence prior to fleeing their country of origin are less likely to desire to return while conflict is ongoing. Prior exposure to violence provides useful heuristics for refugees who prefer avoiding reexposure and likely prefer to return when conflict ends, if at all. Thus, refugees who have been exposed to violence likely feel anchored to their new host state and wish to avoid future risk of trauma. This suggests a conventional understanding of the effects of violence on decision making:

H1: Refugees exposed to violence before they were displaced are less likely to want to return to their country of origin.

Anchoring is also central to our understanding of individual attachments to meaningful locations. Place attachment can augment the anchoring heuristic by serving as a reference point for future decision making. ${ }^{6}$ Such attachments enhance self-esteem and self-efficacy and can provide a bridge for one's identity between prior experiences and future actions (Scannell and Gifford 2010). So, when do people attach or detach from a particular place? Simply stated, place attachments are formed from judgements of satisfaction, expectations of stability, and feelings of positive affect (Shumaker and Taylor 1983). When an individual's aggregate assessment of a location is positive, they are attached and unlikely to detach. When their assessment is negative, they may become detached. Crucial to understanding (in)voluntary relocation, is the idea that an individual's place attachment is neither monolithic nor permanent. Some individuals may have attachments to multiple places simultaneously (Gustafson 2009), and the intensity of attachments between locations likely varies depending on updated cost-benefit analyses (Giuliani 2003).

In migrant decision making, place attachments may constrain the decision to leave home, prompt a decision to leave when losses are intolerable, influence choice of potential destinations, and affect migrants' postmigration experiences (Dandy et al. 2019). Individuals with stronger place attachments are less willing to leave those places. For example, residents exposed to high flood risk have been shown to be less willing to evacuate or relocate if they demonstrated high place attachment (De Dominicis et al. 2015). This is shown with

\footnotetext{
${ }^{6}$ We define place attachment as the process through which people give "culturally shared emotional/ affective meanings to a particular space or piece of land that provides the basis for the individual's ... understanding of and relation to the environment" (Low 1992, 165).
}

Javanese communities remaining in or returning to high risk disaster areas (Lavigne et al. 2008), Norwegian residents' unwillingness to relocate in the case of an oil spill (Kaltenborn 1998), and Australian residents having weaker intentions to leave in the face of a brushfire outbreak (Paton, Burgelt, and Prior 2008). Place attachment might also motivate decisions to return following displacement, even in the face of danger. For instance, rural residents displaced by the Bhakra Nangal Dam Project in the Himalayas continued to search for ways to return to their habitats despite knowing these habitats were at high risk of future flooding (Pirta, Chandel, and Pirta 2014).

Various case studies suggest that exposure to adversity heightens individuals' perception of future risks in conflict settings (Callen et al. 2014; Voors et al. 2012). Exposure can also prompt them to develop adaptive skills to identify threats, find ways to manage them (Brück, d'Errico, and Pietrelli 2018; HernándezCarretero and Carling 2012), and increase their perceived competence to tackle similar situations in the future. Several studies even find individuals become more risk acceptant (Voors et al. 2012) or less risk averse (Bocquého et al. 2018) after being exposed to violence. In the context of refugee decision making, this suggests that refugees exposed to violence prior to their displacement may be more likely to want to return to the locus of violence than are individuals without such prior exposure.

To explain, we assume individuals manage risk and uncertainty associated with new and potential future experiences by relying, in part, on prior experience (Zinn 2008). The underlying logic behind these strategies of risk management "is not one of cause and effect but one of analogy, a situation or event is like a previously experienced situation and therefore the decisions, action, and feelings from the previous situation are pertinent to the current situation" (Zinn 2008, 446). When exposed to violence, individuals develop several skills that enable them to identify threats and minimize risks. For example, Kirschenbaum's (2006, 22) study of terrorism and risk perceptions finds that "one important reason for the marginal impact of terror in Israel has been that individuals, families and larger social groups have adapted their preparedness behaviors so as to minimize its impact." Similarly, when deciding to return to conflict, individuals can draw on their past experiences to assess and manage risks en route or at home.

Anchoring to place can help explain why this might be the case. Individuals attached to their homes may wait until the last minute to make the decision to migrate elsewhere. During that period of waiting, they develop tools to assess the risks they face. For example, individuals exposed to military shelling learn to gauge the distance of shells from the various sounds they make. Recognizing these sounds can help them evaluate when to take cover. If this simple strategy matches reality, individuals will be able to make quick, adaptive decisions to protect themselves against potential harm. This explanation does not homogenize exposure to violence. Rather, each form of violence may be 
associated with the development of unique adaptive strategies that protect them during similar future events. Furthermore, individuals need not be the direct victims of violence to develop expertise; they may also learn through "vicarious reinforcement"-by witnessing the actions of others and their consequences (Bandura 1971).

By adapting to and overcoming obstacles, individuals will enjoy higher self-efficacy and perception of control over adverse events (Bandura 1977). Self-efficacious individuals will tend to tackle threats head-on. ${ }^{7}$ In the context of refugee situations, the ability to identify threats enables individuals to bet on a return to their country of origin even while the threat of violence persists.

The more familiar an event is and the more knowledgeable the individual experiencing it, the less likely they are to fear similar events in the future. A series of studies of responses to terrorist violence and natural disasters illustrate why this might be the case. Societies experiencing rare large-scale terrorist events are more likely to have higher stress and anxiety levels due to the uncertainty shock of the event (Galea et al. 2002; Rubin et al. 2005). However, those experiencing "chronic" terrorism are considerably less likely to exhibit fear and uncertainty regarding future violent events (Spilerman and Stecklov 2009). This may be why risk assessment differs between experts and the public on a wide variety of issues (Slovic 1987). For example, "repeated bombing- related media exposure [after the Boston Marathon bombings] was associated with higher acute stress than was direct exposure" (Holman, Garfin, and Silver 2014). Other research shows residents who refused to evacuate, despite impending warnings of a natural disaster, were those who had successfully overcome similar previous disasters (Strang 2014). Furthermore, individuals who were surveyed about hypothetical disasters exhibited exaggerated concerns if they had not previously lived through an event of the same type (Reinhardt 2017).

Taken together, these logics imply individuals with stronger attachment to their homelands may have been more likely to be exposed to violence prior to fleeing and, thus, may also prefer to return when possible. Additionally, their prior exposure and "expert" status helps to ensure they can better assess and tolerate risk associated with the potential for future exposure. By contrast, refugees who fled their homes prior to direct exposure to violence may have done so because of less attachment to that location and are likely to feel greater uncertainty regarding future potential exposures and, thus, be unwilling to accept the risk. Their skepticism and anxiety about the situation make them less willing

\footnotetext{
${ }^{7}$ Traumatic events have also been shown to increase individuals' perceived competence through posttraumatic growth (PTG). Posttraumatic growth theory holds that personal growth and development can result from "major life crises" (Tedeschi and Calhoun 2004). Individuals who display PTG experience personal improvement in several dimensions-one of the most relevant being a strengthened self-perception (Tedeschi and Calhoun 1996).
}

to return to their country of origin. Accordingly, this leads to the following pair of hypotheses that contradict hypothesis 1 :

H2a: Refugees exposed to violence before displacement are more likely to want to return to their country of origin.

H2b: Refugees with a stronger attachment to their homelands are more likely to want to return to their country of origin.

Finally, social anchor theory posits individuals' social networks in informal and formal social settings serve to anchor them within a community (Clopton and Finch 2011). Social anchors foster a sense of collective identity by contextualizing and rooting personal relationships. Linking identity, security, and integration in migration processes, GrzymalaKazlowska $(2016,1131)$ identifies social anchoring as "the process of finding significant reference: grounded points which allow migrants to restore their sociopsychological stability in new life settings. The anchors people use allow them to locate their place in their world, give form to their own sense of being and provide them with a base for psychological and social functioning."

Social anchors take on various forms, including "legal and institutional (e.g., personal documents, legal status, access to formal institutions), economic (economic resources, consumed goods, types of economic activity), spatial and environmental (such as place of birth, place of residence)... social and professional (e.g., family roles, occupation, being an immigrant), a position in social structure and group belonging (real or imagined)" (Grzymala-Kazlowska 2016, 1131). Anchoring can, thus, be understood as what allows individuals to connect or disconnect from various social and spatial places.

With respect to refugee situations, just as they have previously detached from their home locations, refugees can become anchored to host communities to varying degrees. They may, for example, have familial networks, economic stability through a job, or access to education for their children. Refugees with these social anchors are likely to feel more rooted and secure in the host nation and may perceive returning to their countries of origin to be too risky. Accordingly, this leads to the following hypothesis:

H3: Refugees socially anchored to the host state are less likely to want to return to their country of origin.

\section{RESEARCH DESIGN}

To test our hypotheses, we draw upon an original survey of Syrian refugees in Lebanon. We do so by pursuing two complementary modeling strategies, using observational and experimental elements of our survey. Our observational survey analysis examines our full set of theoretical expectations. We complement these analyses with a conjoint experiment. As our theory suggests, place attachment and prior exposure 
to violence are likely to vary together: individuals most attached to their hometown are those most likely to have been pushed out as violence was closing in on them. The goal of the conjoint experiment is to disentangle these two mechanisms in order to examine whether individuals' prior exposure to violence is likely to affect their risk calculations upon return.

It is important to highlight some key traits of this research design. First, Syrian refugees are the largest single-country share of the global refugee population, and Lebanon hosts the largest per capita population of refugees globally. Accordingly, investigation of this population of Syrian refugees in Lebanon provides a great opportunity to focus upon combinations of preflight characteristics and flight-related factors that appear to influence decision making. ${ }^{8}$ Second, our data collection benefits refugee communities by providing a platform for their preferences in ongoing debates on repatriation. Third, our survey team's priority was doing no harm (Fujii 2012; The Belmont Report 1978; Wood 2006). ${ }^{9}$

\section{Survey Sample}

We surveyed nearly 2,000 Syrian refugees throughout Lebanon during June and July 2018. ${ }^{10}$ According to the official statistics of the UNHCR, over 1,000,000 Syrians are living in Lebanon. They are distributed throughout the country, with $70 \%$ living in residential buildings and $30 \%$ in unofficial settlements and camps. Our goal was to try to ensure the distribution of survey responses reflected the geographic distribution of the refugee population. To do so, we first grouped the eight governorates in Lebanon into four contiguous governorate pairs (regions) and used the known distribution of refugees in these regions to determine a proportionally representative survey distribution per region. ${ }^{11}$

Second, we further distributed the governorate-pair survey quota across the 24 districts of the country, such that the number of responses per district would be proportional to the size of the refugee population in each district, as determined by the UNHCR at the time of fielding. ${ }^{12}$ We then selected towns or settlements within each district such that their probability of being selected was proportional to the size of the

\footnotetext{
${ }^{8} \mathrm{We}$ also asked respondents questions about conditions on the ground in Lebanon; however, these responses vary minimally across our sample. See Mourad (2019) for a deeper understanding of the variation in local migration policies in Lebanon and its impact on the lived experiences of Syrian refugees.

${ }^{9}$ See Appendix B for a comprehensive discussion and evaluation of the ethical challenges faced in this study and the decisions we took to manage them.

${ }^{10}$ The effective number of observations after cleaning the survey was 1,$750 ; 250$ observations were removed due to errors with the survey software.

${ }^{11}$ See Appendix A for a full discussion of the sampling population and survey administration underlying our study, as well as Table 1, which displays the relative distribution of refugees across Lebanon's regions and the associated sample per region.

${ }^{12}$ See Table 2 in Appendix A.
}

refugee population in each town or settlement. Because all refugees must register with municipalities, we were able to obtain a household listing of Syrian refugees for each town. Typically, Syrian refugee households were clustered within a town. Within each town, we used systematic sampling to select households from this listing: the starting household in each town or settlement was randomly selected from the list until an adult respondent who was willing to participate was found (only one individual per household was selected). The enumerator team then skipped three houses to go to the fifth house on the list to request their next participant. This process continued until options in a specific town were exhausted or the required number of surveys were completed. The same method was applied in unofficial settlements: after the first tent was chosen enumerators skipped the next three to choose the fifth.

\section{OBSERVATIONAL ANALYSES}

We focus first on our observational analyses. For our dependent variable, we rely upon a question assessing respondents' feelings about the possibility of returning to Syria. The question asked, "How much do you disagree/agree with the following statement: I would NOT return to Syria under any circumstances." Respondents answered on a seven-point scale ranging from strongly agree (meaning they would NEVER return to Syria) to strongly disagree (meaning they WOULD return to Syria). From the responses, we generate our primary dependent variable, never return ordinal. Given the structure of these data, we run analyses using a series of ordered logistic regressions.

We group our primary independent variables based upon our three hypotheses. Experienced violence is a dichotomous indicator coded 1 if the refugee personally experienced violence in Syria before departing their hometown and 0 otherwise. Each respondent was asked whether they experienced the following: physical assault/beaten, physical and mental torture, abduction, sexual violence, forced labor, wage theft, shot at, or shelling. If the respondent answered that they experienced at least one of these types of violence, the variable is coded as 1 . We use this variable to test the competing hypotheses 1 and 2a.

We then code four variables to test hypothesis $2 b$, which refers to hometown attachment. The first, proportion of hometown that fled, is a categorical variable differentiating individuals who fled when almost none/a small proportion (baseline), half, or most/all of their hometown had already fled. The second, discussed fleeing, is a binary variable, coded 1 if, prior to their displacement, the individual talked about fleeing with their household, neighbors, family, community leaders, local authorities, or on online forums and 0 otherwise. These two variables are closely associated. Both capture whether migration intentions were being formed prior to flight or whether the individual was, instead, pushed out by violence. We expect that, if an individual is attached to their homeland, they are less 
likely to flee unless they are being pushed out by violence. As such, hypothesis $2 b$ would be confirmed by a positive relationship between the proportion of hometown that fled and willingness to return to Syria and a negative relationship between discussed fleeing and willingness to return to Syria. ${ }^{13}$

We also include two additional variables to capture an attachment to the homeland, all dichotomous. The first indicates whether the individuals resides in a Syrian neighborhood in Lebanon. Networks of individuals with a shared community origin provide certain positive externalities that are specific to the location where contacts reside, which include reducing the "psychic costs" of leaving a familiar environment (Barrett and Mosca 2013; Faini and Venturini 2010; Massey et al. 1993; Sjaastad 1962). Living in a location surrounded by individuals with shared community origin helps individuals maintain the familiar connection to their homeland through the maintenance of shared customs and traditions. The second indicates whether the refugee was employed before the outbreak of the war, which would have constituted an important anchor to the homeland.

Finally, to test hypothesis 3 , we create eight binary variables capturing social attachment to Lebanon. Recall that our theory considers social anchors to be any institution - be it social, economic, physical, political, legal - which may be a source of sociopsychological stability for refugees (Clopton and Finch 2011; Grzymala-Kazlowska 2016). Whether an individual has close family in Lebanon who are employed at the time of the survey, whether they think the situation in Lebanon has gotten worse since their arrival, whether they live in a camp, whether they are comfortable reporting crimes, and whether they are registered with the United Nations are all indicators of anchoring and stability. ${ }^{14} \mathrm{We}$ also include whether they believe it is easy to cross the Lebanese/Syrian border. Ease of border crossing facilitates attachment to the host country because it allows individuals to make short trips back to Syria, while keeping their family in Lebanon. Finally, we include whether their household is larger

\footnotetext{
${ }^{13}$ When measuring exposure to violence, Blattman (2009) and Schon (2019) differentiate between violence witnessed, violence received, and violence to family. Our experienced violence indicator is only able to capture "violence received." However, our logic of experiential learning and geographical anchoring would suggest that a violent experience-be it witnessed or received-is associated with learning new adaptive strategies to protect oneself against future harm. Because individuals are more likely to have witnessed violence if their departure was delayed (e.g., Schon 2019), proportion of hometown that fled allows us to tap into this concept by proxy. In Appendix E, we also examine "family experience" using our observational data and find it has near identical effects to "direct experience." Our results are robust to the inclusion of this variable. ${ }^{14}$ UNHCR registration gives refugees security. It is easier for Syrians with a registration certificate from the UNHCR to obtain legal residency and enjoy protection against deportation (Fakhoury 2020, 5). The Lebanese government voted in 2014 to halt the UNHCR from registering any more Syrian refugees. This took effect January 2015, which means those arriving after this time could no longer receive benefits and aid from the UNHCR.
}

than five individuals. As migration is often considered a household decision, that the family has managed to reunite may signal the end of a sequential migration process (Haug 2008).

Our control variables include the length of time, in years, the individual has been displaced from Syria as well as variables measuring individuals' demographic characteristics and their prewar situations. This includes their gender, age, whether they have children, and their prewar income and education. We also include Syrian district fixed effects to account for unobserved heterogeneity based on their hometown locations in their country of origin. ${ }^{15}$

At first glance, the controls lack some intuitively important factors. While the literature on refugee repatriation highlights a lack of economic opportunities in the host state and social networks at home as drivers for return, our survey sample shows no variation in responses on these questions. Almost all respondents say Lebanon has few economic opportunities for refugees. Similarly, almost all refugees still have family and connections remaining in Syria. Additionally, all respondents reported being Sunni Muslim. Thus, we have no variation in identity to leverage. However, this is representative of the Syrian refugee population in Lebanon and not a limitation of our study. While these factors may affect individuals' likelihoods of returning, we are unable to test this given the homogeneity in responses. If anything, this allows us to capture dynamics of the individual's context of flight more clearly.

\section{Results}

To capture a preliminary understanding of our variables of interest, we provide descriptive cross-tabulations in Table 3 in Appendix D. These show that, on average, most refugees disagree with the statement that they would never return to Syria, which provides initial support for a place attachment to the homeland, as proposed in hypothesis 2 . At the same time, some variables capturing an attachment to Lebanon or detachment from Syria show respondents wanting to stay in their host state. For instance, refugees who believe the situation in Lebanon is about the same as before and those who discussed fleeing are more likely to agree with the statement that they would not return to their country of origin. ${ }^{16}$

Next, Table 2 presents the results of our ordered logistic regression assessing whether respondents agreed with the statement that they would never return to Syria. Column (1) displays the results of experiencing violence. Column (2) adds circumstances related to connections to the homeland. Column (3) presents

\footnotetext{
${ }^{15}$ See Appendix $\mathrm{H}$ for additional specifications of geographic heterogeneity. Results are robust to all specifications.

${ }^{16}$ We found a lack of variation with whom respondents discussed fleeing. All respondents either did not discuss fleeing with anyone or only discussed fleeing with their household. However, the fact that they were willing to do so indicates that the respondents felt that they were secure enough to speak openly within their household (Pearlman 2016; Schon 2019).
} 
TABLE 2. Decision to Flee on Desire to Return to Syria at Some Time

\begin{tabular}{|c|c|c|c|c|}
\hline & (1) & (2) & (3) & $(4)$ \\
\hline Experienced violence & $\begin{array}{l}1.205^{\star * *} \\
(0.109)\end{array}$ & $\begin{array}{l}0.735^{\star * *} \\
(0.123)\end{array}$ & & $\begin{array}{l}0.692^{\star \star \star} \\
(0.131)\end{array}$ \\
\hline Half hometown fled & & $\begin{array}{l}1.309^{\star \star \star *} \\
(0.200)\end{array}$ & & $\begin{array}{l}1.243^{\star * \star} \\
(0.236)\end{array}$ \\
\hline Most hometown fled & & $\begin{array}{l}1.272^{\star \star \star} \\
(0.192)\end{array}$ & & $\begin{array}{l}1.194^{\star * *} \\
(0.227)\end{array}$ \\
\hline Discussed fleeing & & $\begin{array}{c}-0.481^{\star \star} \\
(0.168)\end{array}$ & & $\begin{array}{c}-0.488^{\star *} \\
(0.174)\end{array}$ \\
\hline Syrian neighborhood in LBN & & $\begin{array}{l}0.621^{\star \star \star} \\
(0.126)\end{array}$ & & $\begin{array}{l}0.710^{\star * *} \\
(0.143)\end{array}$ \\
\hline Easy border crossing & & $\begin{array}{c}-0.545^{\star \star \star} \\
(0.142)\end{array}$ & & $\begin{array}{c}-0.443^{\star \star} \\
(0.151)\end{array}$ \\
\hline Employed before war & & $\begin{array}{c}-0.079 \\
(0.129)\end{array}$ & & $\begin{array}{c}-0.047 \\
(0.135)\end{array}$ \\
\hline Close family in LBN & & & $\begin{array}{l}0.481^{* \star *} \\
(0.110)\end{array}$ & $\begin{array}{c}0.155 \\
(0.119)\end{array}$ \\
\hline Employed & & & $\begin{array}{l}0.413^{\star *} \\
(0.131)\end{array}$ & $\begin{array}{l}0.423^{\star \star} \\
(0.139)\end{array}$ \\
\hline Situation in LBN is worse & & & $\begin{array}{l}0.847^{\star * \star} \\
(0.136)\end{array}$ & $\begin{array}{c}0.319^{\star} \\
(0.150)\end{array}$ \\
\hline Registered with UN & & & $\begin{array}{l}0.480^{\star \star *} \\
(0.119)\end{array}$ & $\begin{array}{c}0.251^{*} \\
(0.127)\end{array}$ \\
\hline Living in camp & & & $\begin{array}{c}0.037 \\
(0.123)\end{array}$ & $\begin{array}{c}-0.205 \\
(0.145)\end{array}$ \\
\hline Comfortable reporting crimes & & & $\begin{array}{c}0.159 \\
(0.116)\end{array}$ & $\begin{array}{r}-0.260^{t} \\
(0.140)\end{array}$ \\
\hline Household larger than 5 & & & $\begin{array}{r}0.269^{\star} \\
(0.109)\end{array}$ & $\begin{array}{c}0.083 \\
(0.115)\end{array}$ \\
\hline Displaced duration & $\begin{array}{c}0.026 \\
(0.028)\end{array}$ & $\begin{array}{c}0.022 \\
(0.030)\end{array}$ & $\begin{array}{c}-0.009 \\
(0.028)\end{array}$ & $\begin{array}{c}0.019 \\
(0.030)\end{array}$ \\
\hline Intermediate school dropout & $\begin{array}{c}-0.154 \\
(0.115)\end{array}$ & $\begin{array}{c}-0.040 \\
(0.120)\end{array}$ & $\begin{array}{c}-0.186 \\
(0.117)\end{array}$ & $\begin{array}{c}-0.029 \\
(0.122)\end{array}$ \\
\hline Secondary school dropout & $\begin{array}{c}0.222 \\
(0.156)\end{array}$ & $\begin{array}{c}0.243 \\
(0.165)\end{array}$ & $\begin{array}{c}0.131 \\
(0.161)\end{array}$ & $\begin{array}{c}0.276 \\
(0.170)\end{array}$ \\
\hline Secondary school and above & $\begin{array}{c}0.251 \\
(0.249)\end{array}$ & $\begin{array}{r}0.429^{t} \\
(0.256)\end{array}$ & $\begin{array}{c}0.178 \\
(0.251)\end{array}$ & $\begin{array}{c}0.451^{t} \\
(0.260)\end{array}$ \\
\hline Prewar income: $\$ 201-\$ 500$ & $\begin{array}{l}1.217^{\star * *} \\
(0.121)\end{array}$ & $\begin{array}{c}0.150 \\
(0.156)\end{array}$ & $\begin{array}{l}0.958^{\star \star \star} \\
(0.123)\end{array}$ & $\begin{array}{c}0.195 \\
(0.163)\end{array}$ \\
\hline Prewar income: Greater than $\$ 500$ & $\begin{array}{l}0.919^{\star * \star} \\
(0.148)\end{array}$ & $\begin{array}{c}-0.084 \\
(0.191)\end{array}$ & $\begin{array}{l}0.600^{\star * *} \\
(0.155)\end{array}$ & $\begin{array}{c}-0.026 \\
(0.199)\end{array}$ \\
\hline Age & $\begin{array}{c}-0.001 \\
(0.004)\end{array}$ & $\begin{array}{c}0.003 \\
(0.004)\end{array}$ & $\begin{array}{c}-0.003 \\
(0.004)\end{array}$ & $\begin{array}{c}0.004 \\
(0.004)\end{array}$ \\
\hline Married & $\begin{array}{c}0.248 \\
(0.183)\end{array}$ & $\begin{array}{c}0.246 \\
(0.188)\end{array}$ & $\begin{array}{c}0.296 \\
(0.188)\end{array}$ & $\begin{array}{c}0.285 \\
(0.195)\end{array}$ \\
\hline Male & $\begin{array}{c}-0.867^{\text {*** }} \\
(0.107)\end{array}$ & $\begin{array}{c}-0.359^{\star \star} \\
(0.124)\end{array}$ & $\begin{array}{c}-0.944^{\star * \star} \\
(0.113)\end{array}$ & $\begin{array}{c}-0.456^{\star \star \star} \\
(0.130)\end{array}$ \\
\hline Children & $\begin{array}{c}-0.359^{\star} \\
(0.182)\end{array}$ & $\begin{array}{c}-0.300 \\
(0.188)\end{array}$ & $\begin{array}{r}-0.335^{t} \\
(0.188)\end{array}$ & $\begin{array}{r}-0.379^{t} \\
(0.197)\end{array}$ \\
\hline$N$ & 1,518 & 1,486 & 1,484 & 1,453 \\
\hline
\end{tabular}

Note: Syrian hometown fixed effects omitted. ${ }^{\dagger} p<0.1,{ }^{*} p<0.05,{ }^{* \star} p<0.01,{ }^{* \star \star} p<0.001$.

results examining social attachment to the host country. Our final ordered logistic regression in Column (4) includes all variables in one model.

Our theory suggests refugee decision making is influenced by anchoring effects whereby prior exposure to violence affects future decision making. Our primary independent variable of interest, experienced violence, is positive and significant in all model specifications. Our results reflect that refugees who experienced violence are more likely to disagree with the statement that they would never return to Syria under any circumstances, which supports hypothesis $2 \mathrm{a}^{17}$ Individuals are more willing to return to Syria at some point

\footnotetext{
${ }^{17}$ Results are robust to whether the respondent or one of their family members experienced violence. Gender identification returns robust findings.
} 
even if they experienced violence before being displaced from their hometowns. This is consistent with the idea that they might have developed adaptive strategies to identify threats and find ways to manage them and, thus, be more willing to risk exposure to violence upon return than individuals who have not previously been exposed to violence. Further on this point, we refer the reader to a discussion of existing evidence and descriptive statistics on gender and violence in Appendix F. Additional regressions and conjoint analyses show that gender does not appear to significantly condition the relationship between experience with violence and willingness to return, nor does it appear to condition risk calculations. The finding that experiences with violence affect both men and women's willingness to return is striking because acts encountered across genders are very distinct (see Table F.2 in Appendix F). This finding may suggest further support for our hypothesis that refugees exposed to violence in Syria are more likely to have developed adaptive strategies to identify and manage the threats they are likely to encounter upon return - and these threats are likely to be very different depending on whether the refugee identifies as a man or a woman. We also find that men are, in general, less willing to return. This may be due to the prospect of forced conscription (European Institute of Peace 2019).

Our anchoring logic suggests a secondary mechanism, which is intrinsically tied to lived experiences: place attachment. Individuals with greater attachment to their hometown are expected to be most likely to wait until the last minute to flee. This appears to be empirically validated by the observation that the higher the proportion of individuals who had already fled the respondent's hometown the more likely that individual would return to Syria at some stage.

Similarly, if the individual currently resides in a Syrian neighborhood in Lebanon, they also appear to prefer to return to Syria at some stage. However, if individuals discussed fleeing with others before doing so, they are less willing to return to Syria under any circumstance. This suggests that those who had a conversation about the decision to flee did so because they found it easier to detach from their home location in the first instance. These individuals are contrasted with refugees who may not have had the time to discuss migration plans and became displaced against their intention. Employment before the outbreak of the civil war does not seem to influence return intentions.

As per our theoretical framework, evidence for hypothesis $2 \mathrm{a}$ and hypothesis $2 \mathrm{~b}$ jointly support the presence of anchoring to the country of origin. However, we are more confident in our ability to observe our place-attachment mechanisms. Examining when an individual fled in relation to others in their hometown who were at similar risk of encountering violence is a relatively clear measure of place attachment. However, we can only assess individuals' perceived self-efficacy and ability to assess risks indirectly by observing the relationship between lived experiences and return intentions. Our second set of analyses will complement these results by allowing us to examine this mechanism more directly. ${ }^{18}$

Next, we identify variables signifying an attachment to the host state. Refugees who believe that the situation in Lebanon is worse than when they arrived are more likely to prefer return. Also, those who believe it is easy to cross the Lebanese/Syrian border are less likely to desire return, yet this could be explained by the fact it is easy for them to go back and forth informally, meaning there is no need to return formally to war-torn Syria. However, those with close family in Lebanon, a job, and registration with the UN are all more likely to prefer returning to Syria. In other words, we find limited support for hypothesis three on social anchors in the partial Model 3 . Nonetheless, these effects appear more muted in the comprehensive Model 4. It is possible that, while close family, jobs, and legal documentation serve as a social anchors in normal circumstances, Syrian refugees are more likely to have precarious jobs and face a great deal of legal obstacles, even if they are registered with the UNHCR (Nassar and Stel 2019), and may wish to return to Syria with their close family.

Figure 1 displays the average marginal effect of factors leading up to displacement, using results from comprehensive Model 4. The first panel demonstrates that $71.7 \%$ of refugees who experienced violence disagree with the statement that they would never return to Syria. This goes against common assumptions that refugees who experienced violence would never desire to return to their country of origin (hypothesis 1) and offers compelling evidence in support of hypothesis $2 \mathrm{a}$.

The rest of the panels presented in Figure 1 also reflect some rather stark trends; $36.6 \%$ of individuals who discussed fleeing (prior to doing so) agree that they would never return to Syria under any circumstances, compared with $27.4 \%$ that did not have such discussions. Additionally, $37.6 \%$ of refugees who were among the first to flee their hometown disagree that they would never return to Syria, compared with $66.4 \%$ and $68.2 \%$ of those where half or most of their hometown had fled, respectively. Each of these findings offer support for hypothesis $2 b$.

Figure 2 displays the average marginal effects of respondent's perceptions of conditions in the host state. These findings illustrate some evidence for hypothesis 3. The left panel shows that refugees who feel it is easy to cross the Lebanese/Syrian border are more likely to prefer never returning. However, respondents who believe the situation in Lebanon continues to worsen are more likely to prefer returning than those who believe the situation in Lebanon is about the same as before. The middle panel shows that $68.8 \%$ of refugees

\footnotetext{
${ }^{18}$ It is possible that refugees' experiences with violence may have led to them becoming politicized and, therefore, wish to return to Syria as political agents despite the risks involved. This possibility is suggested by Petersen (2011) and Malkki (1995). For ethical reasons, we decided not to ask about political allegiances (See Appendix B). However, we believe the threat of conscription by both the government and opposition as well as the government surveillance of returnees as part of the return and reconciliation process (European Institute of Peace 2019) would make political agency very difficult and, therefore, unlikely to motivate return aspirations.
} 


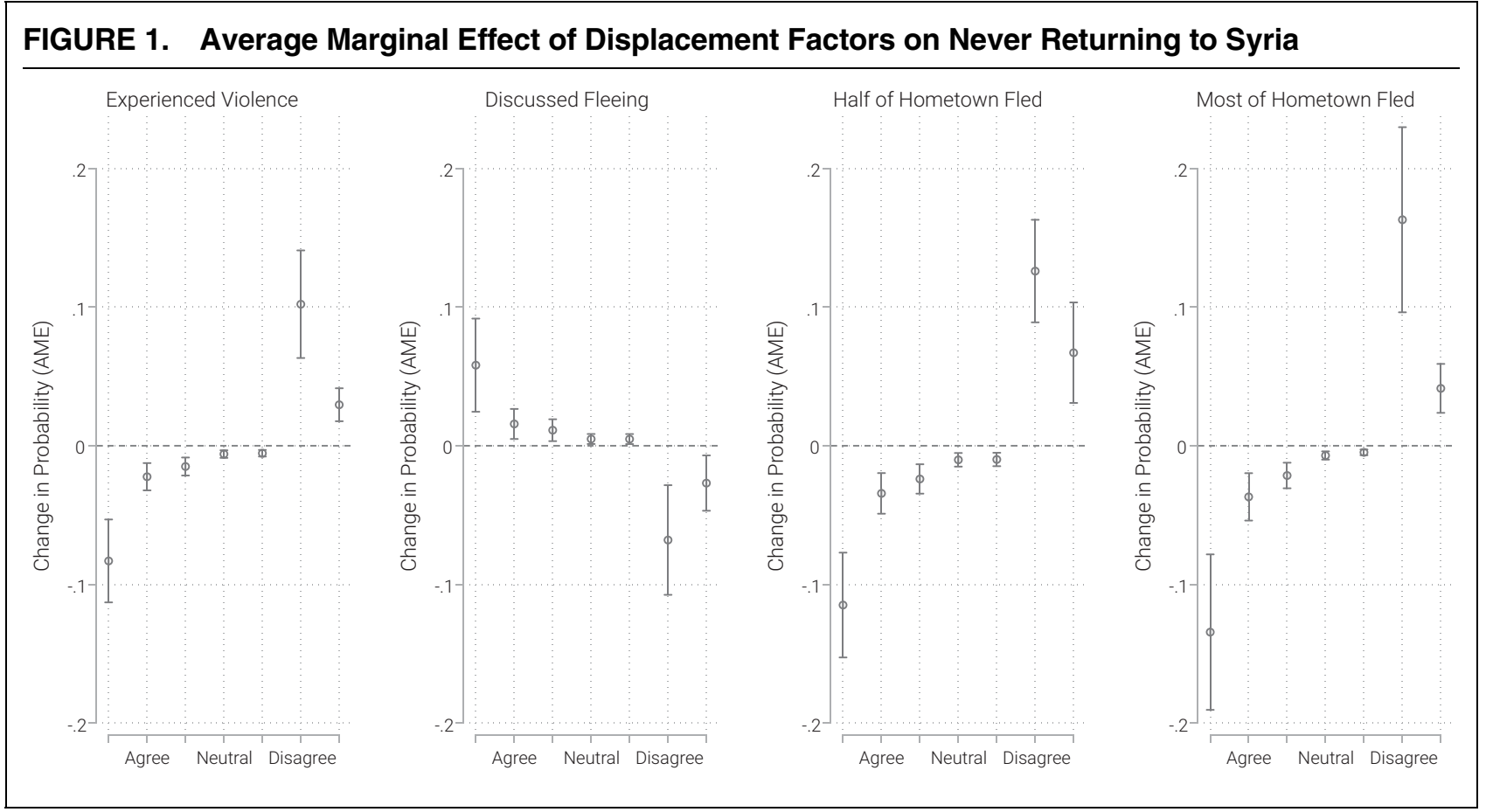

\section{FIGURE 2. Average Marginal Effect of Host Factors on Never Returning to Syria}

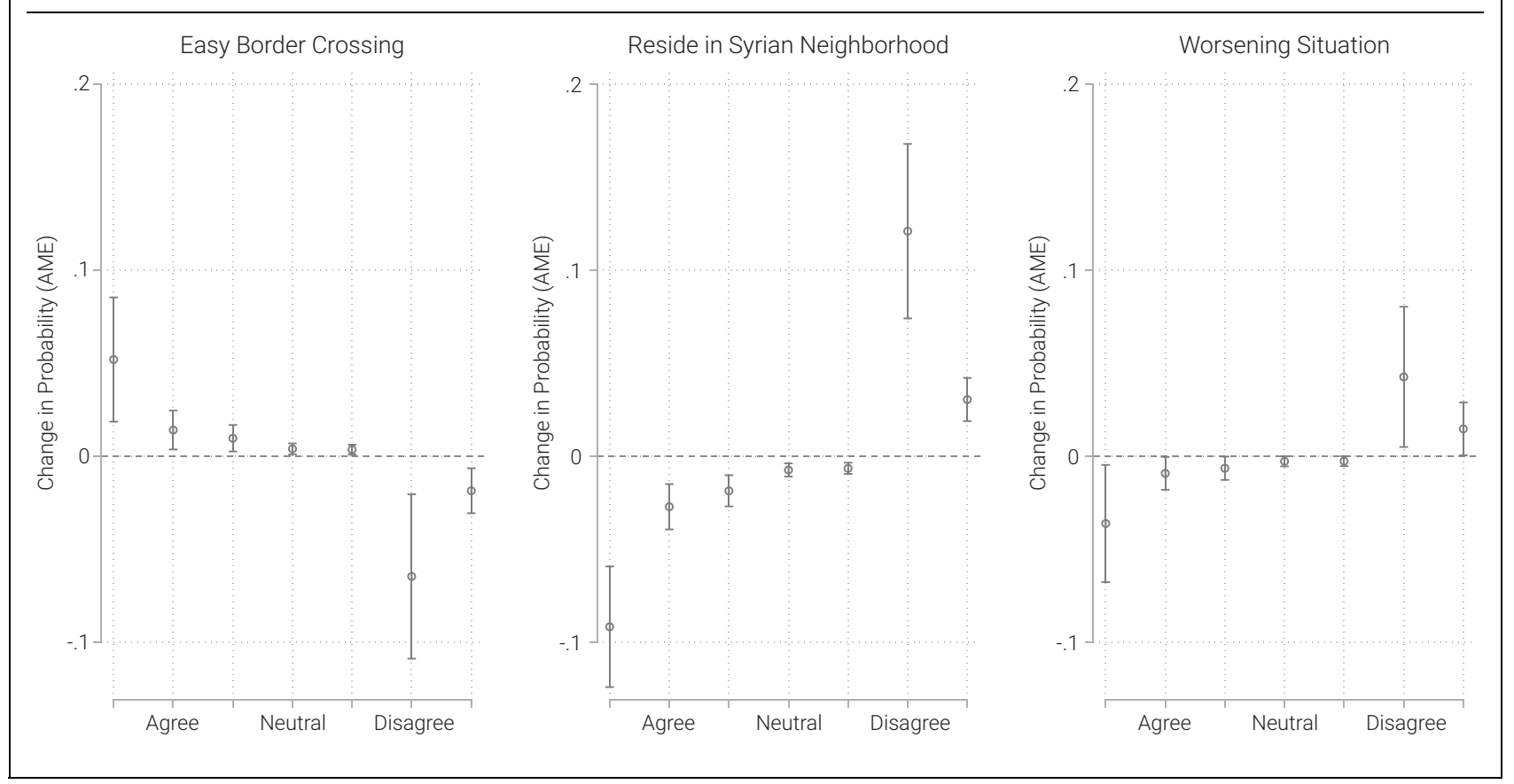

who live in predominantly Syrian neighborhoods in Lebanon want to return at some point, signaling an attachment to home rather than host.

\section{CONJOINT ANALYSES}

In the above analyses, we find individuals that experienced harm before fleeing are more likely to consider returning when conflict is ongoing. In this section, we probe this further. In hypothesis $2 \mathrm{a}$, we posited refugees directly exposed to violence in Syria are more likely to have developed adaptive strategies to identify threats and manage them. This means they are more likely to risk exposure to violence upon return than individuals not previously exposed to violence. However, individuals exposed to violence are also likely to be those with greater place attachment, who waited until the last minute to flee. As we posit in hypothesis $2 \mathrm{~b}$, place attachment is likely to drive return decisions in its own right. 
Because place attachment and prior exposure to violence are likely correlated, it is difficult to disentangle these explanations using standard survey items. We use a conjoint experiment to isolate the effects of prior exposure to harm on risk assessment upon return to Syria (hypothesis 1 and hypothesis $2 \mathrm{a}$ ). That is, we seek to examine risk assessment independently from confounding variables such as hometown attachment.

In the conjoint setup, respondents are given two hypothetical destinations in Syria to which to consider returning. These destinations vary in terms of key attributes, including probability of violence en route. Because the attributes of the choice are varied randomly across return options and across a series of choice tasks, we are able to examine the effects of a respondent's prior exposure to harm on return risk calculations independent of hometown attachment or other confounding variables. Our theoretical framework suggests that individuals' heterogeneous lived experiences will affect assessments on return to their hometown-a setting where they encountered these experiences. In the conjoint analyses, we expect individuals to factor their actual prior experiences into their conception of what harm could look like en route to a hypothetical destination.

A random sample of 406 respondents from our survey sample were each presented with five return tasks consisting of a choice between two location profiles, each consisting of four attributes. Of interest here is the attribute "chance of harm en route to that location." However, we also included the chance of a peaceful situation lasting at least a year there, the number of people the hypothetical migrant would know there, and the ease of finding work. These tasks prompted individuals to consider a hypothetical migrant like themselves: "I would like you to imagine a person, like yourself, but this person is considering a return to Syria. I would like you to consider the following two places in Syria, where there is currently no fighting taking place, and I would like you to tell me which place in Syria you think this person should go to." Respondents were then asked to state their preferred choice from two hypothetical alternatives in Syria generically labeled "Place A" and "Place B." Respondents were asked to choose between one of these two location alternatives or skip the task if they did not know or did not want to answer. On average, each respondent completed 4.9 tasks. The values for each attribute were independently and randomly varied as per the levels shown in Table 3. An example of a choice task is shown in Table 4.

In our analysis, we follow the statistical approach for conjoint analysis developed in Hainmueller, Hopkins, and Yamamoto (2014). Specifically, we estimate the average causal effect of an attribute level relative to a baseline level, or the average marginal component effect (AMCE). The AMCEs are akin to treatment effects in a standard survey experiment, where the treatment is compared with a particular control condition (Bansak et al. 2021, 15; Leeper, Hobolt, and Tilley 2020). This is possible due to the randomization of the attribute levels whereby the effect of a level on the probability of choice is estimated by taking the probability that alternatives

\section{TABLE 3. Attributes and Possible Levels for} the Conjoint Experiment

\begin{tabular}{ll}
\hline Attribute & Levels \\
\hline $\begin{array}{l}\text { Chance of harm on route to } \\
\text { destination }\end{array}$ & $\begin{array}{c}\text { Low, moderate, } \\
\text { high } \\
\text { Chance of peaceful situation lasting } \\
\text { Low, moderate, } \\
\text { at least a year } \\
\text { humber of people they know living } \\
\text { there }\end{array}$ \\
$\begin{array}{c}\text { None, some, } \\
\text { Ease of finding work }\end{array}$ & many \\
& difficult \\
\hline
\end{tabular}

\section{TABLE 4. Example of Choices from the Conjoint Experiment}

\begin{tabular}{lll}
\hline & Place A & Place B \\
\hline $\begin{array}{l}\text { Chance of harm on route to } \\
\text { destination }\end{array}$ & Low & Low \\
$\begin{array}{c}\text { Chance of peaceful situation } \\
\text { lasting at least a year }\end{array}$ & High & Low \\
$\begin{array}{c}\text { Number of people they know } \\
\text { living there }\end{array}$ & Some & Many \\
Ease of finding work & Difficult & Difficult \\
\hline
\end{tabular}

with that level, across all sampled levels of all the other attributes, are chosen compared with alternatives with a different level of that attribute.

In our conjoint, the assignment of levels to profiles is fully random such that each respondent has an equal chance of viewing any given attribute-level combination (out of all possible combinations) within a profile. As such, the sets of profiles involving each level should be balanced (Hainmueller, Hopkins, and Yamamoto 2014). This can be investigated by looking at the omnibus tests of the fits of regression models of any of the respondent characteristics against the attribute levels. As shown in Appendix G, we find no evidence of imbalance (all $p>$ 0.05 ) with respect to any of our variables.

Figure 3 shows the causal effect of the change in the attribute level from the reference level of the conjoint experiment. The left panel displays all observations, the middle panel shows estimates from those who did not experience violence, and the right panel displays effects of respondents who experienced violence prior to their displacement. The unconditional results show that refugees prefer to return to locations in Syria where there is a smaller chance of experiencing harm on the journey there. This effect is similar when examining refugees who did not experience violence firsthand before fleeing. On the other hand, of refugees who experienced violence, there is no statistically significant difference between moderate and low levels of harm en route. This supports our argument that refugees who lived through violence likely perceive that they are well placed to manage the potential for harm on a future journey. The only other attribute with a statistically significant effect was ease of finding work: refugees who believed it would be hard for them to find employment were less 


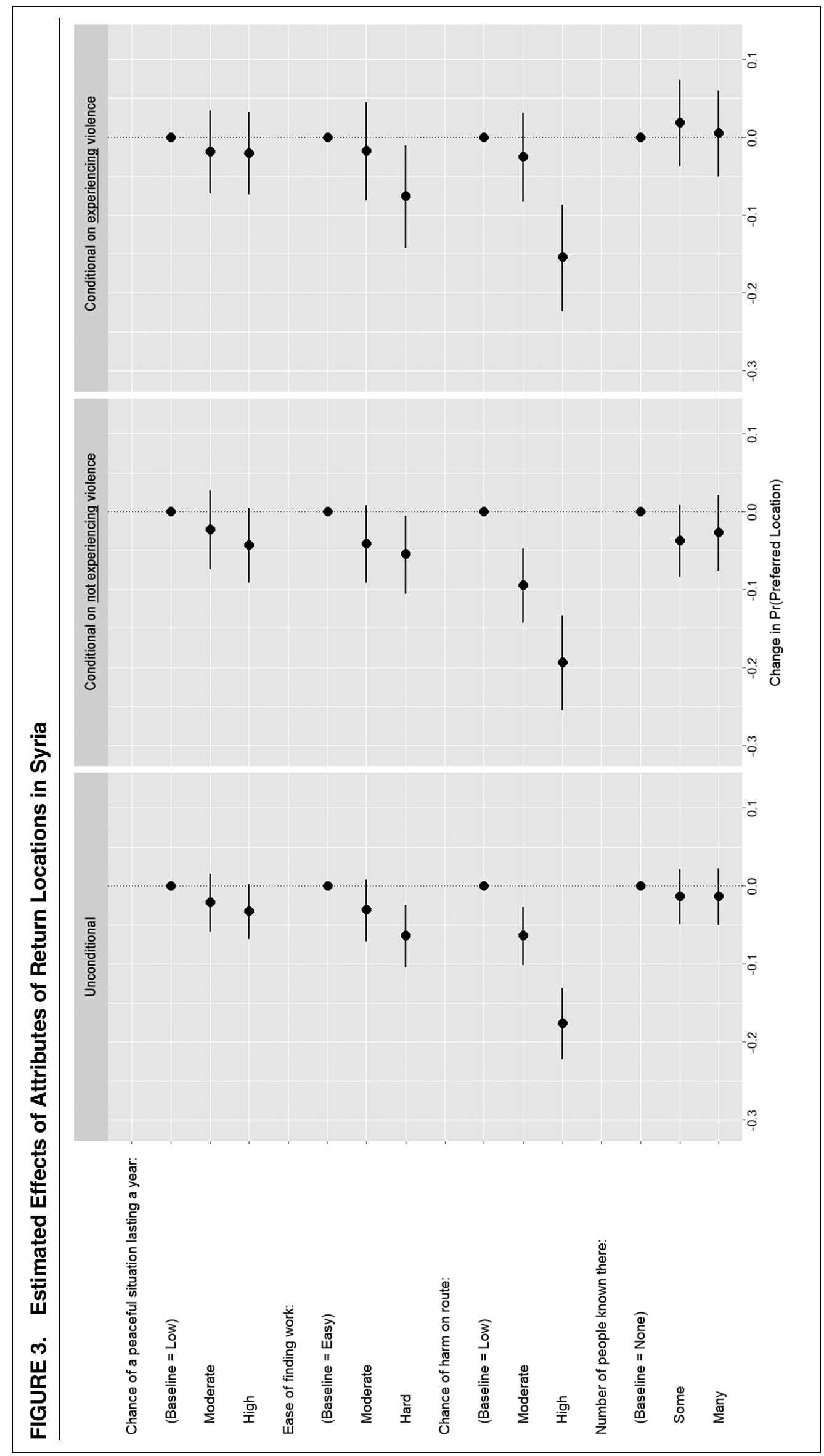


likely to choose that location. This seems intuitive and aligns with expectations from the existing literature.

\section{CONCLUSION}

There are now 26 million refugees globally: the largest such number since the end of World War II. Existing policies dealing with refugee crises neither ease the disproportionate burden on neighboring countries serving as hosts nor strengthen temporary protections until repatriation is deemed feasible. This pushes attention toward the possibility of voluntary repatriation as a solution to protracted refugee situations. However, even though we have witnessed a slight uptick in levels of repatriation in recent years, this still benefits no more than $5 \%$ of the total global refugee population and is often critiqued as being forced rather than voluntary. Nonetheless, refugees wish to return to their homes. It is important, therefore, to understand these preferences before knowing whether to recommend pushing an agenda for more comprehensive repatriation. Indeed, states need to protect the right to return safely and in dignity of refugees who wish to repatriate. This is necessary to both uphold their human rights and recognize their agency as they renegotiate their relationship with their nation state, as citizens (Bradley 2013).

This paper addresses this gap by asking what factors inform refugees' preferences regarding the potential to return home. To answer this question, we deployed an original survey of nearly 2,000 Syrian refugees in Lebanon. Both observational and experimental analyses demonstrate those who were exposed to violence prior to their displacement to Lebanon wish to return to Syria. We argue these refugees harbor a stronger attachment to Syria, while also better understanding their tolerance of violence, because they are "experts" and are more capable of assessing risk. In contrast, refugees who were not directly exposed to violence before fleeing are more unsure of the threats associated with returning and are unwilling to accept the risk of doing so.

We also find that individuals who endured the difficulties of the Syrian Civil War longer than most of their hometown's fellow residents are more likely to desire to return to Syria. The same is true of those who settled in predominantly Syrian neighborhoods in Lebanon. We argue that these effects are also observed effects of anchoring to their homeland.

At the same time, some refugees develop a sense of attachment to their host country. While socioeconomic indicators such as employment or living with family do not anchor our sample of refugees to their host state, other conditions, such as the situation in Lebanon and ease of crossing the border, influence preferences to return. These findings suggest that refugees can develop different preferences regarding returning home and that this may depend upon relative attachment to home and host countries.

Asylum rights globally are being eroded, particularly since developed states refuse to contribute to providing safe haven to refugees. As developing states continue to take on most of the physical responsibility for accommodating refugees, we offer tentative policy recommendations. More attention needs to be paid to the conditions on the ground in these overburdened neighboring states. Only by enhancing refugee experiences in the host country can we expect to encourage more refugees to want to remain in the relatively safe conditions of the host state. Beyond this, it is necessary to work to better accommodate refugees who hold strong preferences to return. This presumably means finding ways of ensuring safe passage for refugees to complete voluntary repatriation while also working to protect against coerced repatriation.

\section{SUPPLEMENTARY MATERIALS}

To view supplementary material for this article, please visit http://dx.doi.org/10.1017/S0003055421000344.

\section{DATA AVAILABILITY STATEMENT}

Research documentation and data that support the findings of this study are openly available at the American Political Science Review Dataverse: https://doi.org/ 10.7910/DVN/UGIOMH.

\section{ACKNOWLEGMENTS}

Previous drafts of this manuscript were presented at the annual meetings of the 2019 American Political Science Association and 2020 Southern Political Science Association, and we would like to thank all participants for their comments and suggestions. We would also like to thank Laura Bakkensen, Christopher Blair, Kanisha Bond, Rana Khoury, Milli Lake, Sarah Parkinson, Justin Schon, Stephanie Schwartz, Jim Walsh, Beth Wellman, and Beth Whitaker, as well as the editors and three anonymous reviewers for their helpful feedback on the project.

\section{FUNDING STATEMENT}

The research was funded in part by award W911NF-17-1-0030 from the Department of Defense and U.S. Army Research Office/Army Research Laboratory under the Minerva Research Initiative. The views expressed are those of the authors and should not be attributed to the Department of Defense or the Army Research Office/Army Research Laboratory.

\section{CONFLICT OF INTEREST}

The authors declare no conflicts of interest in this research.

\section{ETHICAL STANDARDS}

The authors declare the human subjects research in this article was deemed exempt from review by the 
University of Arizona. The authors affirm that this article adheres to the APSA's Principles and Guidance on Human Subject Research. The authors have disclosed ethical issues related to this research in Appendix B.

\section{REFERENCES}

Adelman, Howard, and Elazar Barkan. 2011. No Return, No Refuge: Rites and Rights in Minority Repatriation. New York: Columbia University Press.

Adhikari, Prakash. 2012. "The Plight of the Forgotten Ones: Civil War and Forced Migration." International Studies Quarterly 56 (3): 590-606.

Akar, Sevda, and M. Mustafa Erdoğdu. 2019. "Syrian Refugees in Turkey and Integration Problem Ahead.” Journal of International Migration and Integration 20: 925-40.

Al-Khateeb, Firas, and Vivian Toumeh. 2017. "Aleppo Returnees Assess Scale of Rebuilding." UNHCR, November 13, 2011. www.unhcr.org/news/latest/2017/11/5a096a894/ aleppo-returneesassess-scale-rebuilding.html.

Alsharabati, Carole, and Jihad Nammour. 2017. "Survey on Perceptions of Syrian Refugees in Lebanon: Between Resilience and Vulnerability." Universite Saint-Joseph de Beyrouth. Working Paper.

Bandura, Albert. 1971. Social Learning Theory. Morristown, NJ: General Learning Press.

Bandura, Albert. 1977. "Self-efficacy: Toward a Unifying Theory of Behavioral Change." Psychological Review 84 (2): 191-15.

Bansak, Kirk, Jens Hainmueller, Daniel J. Hopkins, and Teppei Yamamoto. 2021. "Conjoint Survey Experiments." In Cambridge Handbook of Advances in Experimental Political Science, eds. James Druckman and Donald Green, 19-41. New York: Cambridge University Press.

Barnett, Michael. 2001. "Humanitarianism with a Sovereign Face: UNHCR in the Global Under- tow." International Migration Review 35 (1): 244-77.

Barnett, Michael, and Martha Finnemore. 2004. Rules for the World: International Organizations in Global Politics. Ithaca, NY: Cornell University Press.

Barrett, Alan, and Irene Mosca. 2013. "The Psychic Costs of Migration: Evidence from Irish Return Migrants." Journal of Population Economics 26 (2): 483-506.

Berlin Social Science Center. 2015. "Listen to Refugees: First Survey of Syrian Refugees in Europe." The Syrian Campaign, October 9, 2015. https://diary.thesyriacampaign.org/what-refugees-think/.

Black, Richard, and Saskia Gent. 2006. "Sustainable Return in Postconflict Contexts." International Migration 44 (3): 15-38.

Blattman, Christopher. 2009. "From Violence to Voting: War and Political Participation in Uganda." American Political Science Review 103 (2): 231-47.

Bocquého, Géraldine, Marc Deschamps, Jenny Helstroffer, Julien Jacob, and Majlinda Joxhe. 2018. "Risk and Refugee Migration." Observatoire Francais des Conjonctures Economiques. Technical Report.

Bradley, Megan. 2013. Refugee Repatriation: Justice, Responsibility and Redress. New York: Cambridge University Press.

Brück, Tilman, Marco d'Errico, and Rebecca Pietrelli. 2018. "The Effects of Violent Conflict on Household Resilience and Food Security: Evidence from the 2014 Gaza Conflict." Households in Conflict Network. Working Paper 269.

Callen, Michael, Mohammad Isaqzadeh, James D. Long, and Charles Sprenger. 2014. "Violence and Risk Preference: Experimental Evidence from Afghanistan." American Economic Review 104 (1): 123-48.

Cameron, Lisa, and Manisha Shah. 2015. "Risking-taking Behavior in the Wake of Natural Disasters." Journal of Human Resources 50 (2): 484-515.

Cervone, Daniel, and Philip K. Peake. 1986. "Anchoring, Efficacy, and Action: The Influence of Judgmental Heuristics on Selfefficacy Judgments and Behavior." Journal of Personality and Social Psychology 50 (3): 492-501.
Chu, Tiffany S. 2019. Examining the Conditions of Refugee Repatriation. PhD diss. University of Arizona.

Clopton, Aaron Walter, and Bryan L. Finch. 2011. "Reconceptualizing Social Anchors in Community Development: Utilizing Social Anchor Theory to Create Social Capital's Third Dimension." Community Development 42 (1): 70-83.

Dandy, Justine, Pierre Horwitz, Robert Campbell, Deirdre Drake, and Zoe Leviston. 2019. "Leaving Home: Place Attachment and Decisions to Move in the Face of Environmental Change." Regional Environmental Change 19 (2): 615-20.

Davenport, Christian, Will H. Moore, and Steven Poe. 2003. "Sometimes You Just Have to Leave: Domestic Threats and Forced Migration, 1964-1989." International Interactions 29 (1): $27-55$.

De Dominicis, Stefano, Ferdinando Fornara, Uberta Ganucci Cancellieri, Clare Twigger-Ross, and Marino Bonaiuto. 2015. "We are at Risk, and so What? Place Attachment, Environmental Risk Perceptions and Preventive Coping behaviors." Journal of Environmental Psychology 43: 66-78.

Eckel, Catherine C., Mahmoud A. El-Gamal, and Rick K. Wilson. 2009. "Risk Loving after the Storm: A Bayesian-network Study of Hurricane Katrina Evacuees." Journal of Economic Behavior \& Organization 69 (2): 110-24.

European Institute of Peace. 2019. "Refugee Return in Syria: Security Risks and Information Scarcity." European Institute of Peace Brussels. Technical Report.

Faini, Riccardo, and Alessandra Venturini. 2010. "Development and Migration: Lessons from Southern Europe." In Migration and Culture, eds. Gil Epstein and Ira Gang, 105-36. West Yorkshire, UK: Emerald Group Publishing Limited.

Fakhoury, Tamirace. 2020. "Refugee Return and Fragmented Governance in the Host State: Displaced Syrians in the Face of Lebanon's Divided Politics." Third World Quarterly 42 (1): 1653-71.

Ferris, Elizabeth. 2018. "When Refugee Displacement Drags on, is Self-reliance the Answer?" Brookings Institute [blog], June 19, 2018. https://www.brookings.edu/blog/order-fromchaos/2018/06/19/when-refugee-displacement-drags-on-is-selfreliance-the-answer/.

Fleurkens, Pascal, Mike Rinck, and Agnes Van Minnen. 2014. "Implicit and Explicit Avoidance in Sexual Trauma Victims Suffering from Posttraumatic Stress Disorder: A Pilot Study." European Journal of Psychotraumatology 5 (1): 21359.

Fujii, Lee Ann. 2012. "Research Ethics 101: Dilemmas and Responsibilities.” PS: Political Science \& Politics 45 (4): 717-23.

Furnham, Adrian, and Hua Chu Boo. 2011. "A Literature Review of the Anchoring Effect." The Journal of Socioeconomics 40 (1): $35-42$.

Galea, Sandro, Jennifer Ahern, Heidi Resnick, Dean Kilpatrick, Michael Bucuvalas, Joel Gold, and David Vlahov. 2002. "Psychological Sequelae of the September 11 Terrorist Attacks in New York City." New England Journal of Medicine 346 (13): 982-87.

Gerver, Mollie. 2014. "The Role of Non-governmental Organizations in the Repatriation of Refugees." Philosophy and Public Policy Quarterly 32 (1): 2-13.

Ghosn, Faten, Alex Braithwaite, and Tiffany S. Chu. 2019.

"Violence, Displacement, Contact, and Attitudes toward Hosting Refugees." Journal of Peace Research 56 (1): 118-33.

Ghosn, Faten, Tiffany S. Chu, Miranda Simon, Alex Braithwaite, Michael Frith, and Joanna Jandali. 2021. "Replication Data for: The Journey Home: Violence, Anchoring, and Refugee Decisions to Return." Harvard Dataverse. Dataset. https://doi.org/10.7910/ DVN/UGIOMH.

Giuliani, Maria Vittoria. 2003. "Theory of Attachment and Place Attachment." In Psychological Theories for Environmental Issues, eds. Mirilia Bonnes, Terence Lee, and Marino Bonaiuto, 137-70. New York: Routledge.

Grzymala-Kazlowska, Aleksandra. 2016. "Social Anchoring. Immigrant Identity, Security and Integration Reconnected?" Sociology 50 (6): 1123-39.

Gustafson, Per. 2009. "Mobility and Territorial Belonging." Environment and Behavior 41 (4): 490-508.

Hainmueller, Jens, Daniel J. Hopkins, and Teppei Yamamoto. 2014. "Causal Inference in Conjoint Analysis: Understanding Multidimensional Choices via Stated Preference Experiments." Political Analysis 22 (1): 1-30. 
Hammerstad, Anne. 2000. "Whose Security? UNHCR, Refugee Protection and State Security after the Cold War." Security Dialogue 31 (4): 391-403.

Haug, Sonja. 2008. "Migration Networks and Migration Decisionmaking." Journal of Ethnic and Migration Studies 34 (4): 585-605.

Hernández-Carretero, Maŕa, and Jørgen Carling. 2012. "Beyond 'Kamikaze Migrants': Risk Taking in West African Boat Migration to Europe." Human Organization 71 (4): 407-16.

Holman, E. Alison, Dana Rose Garfin, and Roxane Cohen Silver. 2014. "Media's Role in Broad-casting Acute Stress Following the Boston Marathon Bombings." Proceedings of the National Academy of Sciences 111 (1): 93-8.

Johnson, Dominic. 2020. Strategic Instincts: The Adaptive Advantages of Cognitive Biases in International Politics. Princeton, NJ: Princeton University Press.

Kaltenborn, Bjørn P. 1998. "Effects of Sense of Place on Responses to Environmental Impacts: A Study among Residents in Svalbard in the Norwegian High Arctic." Applied Geography 18 (2): $169-89$.

Kirschenbaum, Alan. 2006. "Terror, Adaptation and Preparedness: A Trilogy for Survival." Journal of Homeland Security and Emergency Management 3 (1): 1-33.

Koser, Khalid. 1997. "Information and Repatriation: The Case of Mozambican Refugees in Malawi." Journal of Refugee Studies 10 (1): $1-18$.

Kuhlman, Todd. 1990. "The Economic Integration of Refugees in Developing Countries: A Research Model." Series Research Memoranda 35: 1-28.

Lavigne, Franck, Benjamin De Coster, Nancy Juvin, François Flohic, Jean-Christophe Gaillard, Pauline Texier, Julie Morin et al. 2008. "People's Behavior in the Face of Volcanic Hazards: Perspectives from Javanese Communities, Indonesia." Journal of Volcanology and Geothermal Research 172 (3-4): 273-87.

Leeper, Thomas J., Sara B. Hobolt, and James Tilley. 2020. "Measuring Subgroup Preferences in Conjoint Experiments." Political Analysis 28 (2): 207-21.

Loughran, Catriona, and Ahmed Aden. 2019. "Leaving Safety, Re turning Home to Fear." Norwegian Refugee Council. www.nrc.no/ perspectives/2019/ https:/www.nrc.no/perspectives/2019/returninghome-after-a-lifetime-in-a-refugee-camp/.

Low, Setha M. 1992. "Symbolic Ties That Bind." In Place Attachment, eds. Irwin Altman and Setha Low, 165-85. Boston Springer.

Malkki, Liisa H. 1995. Purity and Exile: Violence, Memory, and National Cosmology among Hutu Refugees in Tanzania. Chicago: University of Chicago Press.

Massey, Douglas, Joaquin Arango, Graeme Hugo, Ali Kouaouci, Adela Pellegrino, and J. Edward Taylor. 1993. "Theories of International Migration: Review and Appraisal." Population and Development Review 19 (3): 431-66.

McKernan, Bethan. 2019. "Syrian Refugees Return to Hometowns in 'Safe Zone' Despite Dangers.” The Guardian, December 18, 2019. www.theguardian.com/world/2019/dec/18/ syrian-refugees-returnto-home-towns-in-safe-zone-despite-dangers.

Moore, Will H., and Stephen M. Shellman. 2006. "Refugee or Internally Displaced Person? To Where Should One Flee?" Comparative Political Studies 39 (5): 599-622.

Moore, Will H., and Stephen M. Shellman. 2007. "Whither Will They Go? A Global Study of Refugees' Destinations, 1965-1995." International Studies Quarterly 51 (4): 811-34.

Mourad, Lama. 2019. Open Borders, Local Closures: Decentralization and the Lebanese Response to the Syrian Refugee Crisis. PhD diss. University of Toronto.

Nassar, Jessy, and Nora Stel. 2019. "Lebanon's Response to The Syrian Refugee Crisis: Institutional Ambiguity as a Governance Strategy." Political Geography 70: 44-54.

Neumayer, Eric. 2004. "Asylum Destination Choice: What Makes Some West European Countries More Attractive than Others?" European Union Politics 5 (2): 155-80.

Orchard, Phil. 2014. A Right to Flee: Refugees, States, and the Construction of International Cooperation. Cambridge: Cambridge University Press.
Parkinson, Sarah E., and Orkideh Behrouzan. 2015. "Negotiating Health and Life: Syrian Refugees and the Politics of Access in Lebanon." Social Science and Medicine 146: 324-31.

Paton, Douglas, Petra Burgelt, and Tim Prior. 2008. "Living with Bushfire Risk: Social and Environmental Influences on Preparedness." Australian Journal of Emergency Management 23 (3): 41-8.

Pearlman, Wendy. 2016. "Narratives of Fear in Syria." Perspectives on Politics 14 (1): 21-37.

Petersen, Roger D. 2011. Western Intervention in the Balkans: The Strategic Use of Emotion in Conflict. Cambridge: Cambridge University Press.

Pirta, Raghubir Singh, Nitin Chandel, and Chhaya Pirta. 2014 "Attachment and Displacement: The Resettlers of Bhakra Dam Are Hurt.” Psychological Studies 59 (1): 1-10.

Reinhardt, Gina Yannitell. 2017. "Imagining Worse than Reality: Comparing Beliefs and Intentions between Disaster Evacuees and Survey Respondents." Journal of Risk Research 20 (2): 169-94.

Rubin, G. James, Chris R. Brewin, Neil Greenberg, John Simpson, and Simon Wessely. 2005. "Psychological and Behavioral Reactions to the Bombings in London on 7 July 2005: Cross Sectional Survey of a Representative Sample of Londoners." British Medical Journal 331 (7517): 606.

Salehyan, Idean. 2018. The Strategic Case for Refugee Resettlement. Washington, DC: Niskanen Center.

Scannell, Leila, and Robert Gifford. 2010. "Defining Place Attachment: A Tripartite Organizing Framework." Journal of Environmental Psychology 30 (1): 1-10.

Schmeidl, Susanne. 1997. "Exploring the Causes of Forced Migration: A Pooled Time-series Analysis, 1971-1990.” Social Science Quarterly 78 (2): 284-308.

Schon, Justin. 2019. "Motivation and Opportunity for Conflict Induced Migration: An Analysis of Syrian Migration Timing." Journal of Peace Research 56 (1): 12-27.

Schwartz, Stephanie. 2019. "Home, Again: Refugee Return and Post-conflict Violence in Burundi.” International Security 44 (2): 110-45.

Shumaker, Sally A, and Ralph B. Taylor. 1983. "Toward a Clarification of People-Place Relationships: A Model of Attachment to Place." Environmental Psychology: Directions and Perspectives 2: 19-25.

Simon, Herbert A. 1972. "Theories of Bounded Rationality." Decision and Organization 1 (1): 161-76.

Sjaastad, Larry A. 1962. "The Costs and Returns of Human Migration." Journal of Political Economy 70 (5, Part 2): 80-93.

Slovic, Paul. 1972. "From Shakespeare to Simon: Speculations - and Some Evidence-about Man's Ability to Process Information." Oregon Research Institute Bulletin 12 (12): 1-19.

Slovic, Paul. 1987. "Perception of Risk." Science 236 (4799): 280-85. Spilerman, Seymour, and Guy Stecklov. 2009. "Societal Responses to Terrorist Attacks." Annual Review of Sociology 35: 167-89.

Steele, Abbey. 2009. "Seeking Safety: Avoiding Displacement and Choosing Destinations in Civil Wars." Journal of Peace Research 46 (3): 419-30.

Steele, Abbey. 2019. "Civilian Resettlement Patterns in Civil War." Journal of Peace Research 56 (1): 28-41.

Stein, Barry N., and Frederick C. Cuny. 1994. "Refugee Repatriation during Conflict: Protection and Post-return Assistance." Development in Practice 4 (3): 173-87.

Strang, Kenneth David. 2014. "Assessing Natural Disaster Survivor Evacuation Attitudes to Inform Social Policy." International Journal of Sociology and Social Policy 34 (7-8): 485-510.

Switzer III, Fred S., and Janet A. Sniezek. 1991. "Judgment Processes in Motivation: Anchoring and Adjustment Effects on Judgment and Behavior." Organizational Behavior and Human Decision Processes 49 (2): 208-29.

Tedeschi, Richard G., and Lawrence G. Calhoun. 1996. "The Posttraumatic Growth Inventory: Measuring the Positive Legacy of Trauma." Journal of Traumatic Stress 9 (3): 455-71.

Tedeschi, Richard G., and Lawrence G. Calhoun. 2004. "A Clinical Approach to Posttraumatic Growth." In Positive Psychology in 
Practice, eds. P. Alex Linley and Stephen Joseph, 405-19. Hoboken, NJ: John Wiley \& Sons.

The Belmont Report. 1978. The Belmont Report: Ethical

Principles and Guidelines for The Protection of Human Subjects of

Research. Vol. 2. Washington, DC: National Commission for the

Protection of Human Subjects of Biomedical and Behavioral

Research.

Tversky, Amos, and Daniel Kahneman. 1974. "Judgment under Uncertainty: Heuristics and Biases." Science 185: 1124-31.
Voors, Maarten J., Eleonora Nillesen, Philip Verwimp, Erwin H. Bulte, Robert Lensink, and Daan P. Van Soest. 2012. "Violent Conflict and Behavior: A Field Experiment in Burundi." American Economic Review 102 (2): 941-64.

Wood, Elisabeth Jean. 2006. "The Ethical Challenges of Field Research in Conflict Zones." Qualitative Sociology 29 (3): 373-86. Zinn, Jens O. 2008. "Heading into the Unknown: Everyday Strategies for Managing Risk and Uncertainty." Health, Risk and Society 10 (5): 439-50. 